VOLUME 14 NOMOR 1 TAHUN 2021

P-ISSN : 1979-9357

E-ISSN : 2620-5858

\title{
Cak Nur: Intelektual Cerdas Indonesia (Studi Biografi)
}

\author{
Ahmad Nabil Amirl, Tasnim Abdul Rahman² \\ Persiaran Tuanku Syed Sirajuddin, Kuala Lumpur, Malaysia ${ }^{1}$, Universiti Sultan Zainal \\ Abidin (UniSZA), Kuala Nerus Terengganu² \\ nabiller2002@yahoo.co.uk ${ }^{1}$, tasnimrahman@unisza.edu.my ${ }^{2}$
}

\begin{abstract}
Looking from its surface, the highly superior and exceptional works of Nurcholish Madjid seems to invite his readers to argue and converse with him with absolute freedom without giving bother to any accusations or charges of anarchy. His writings that was full with philosophical arguments was constructed to inspired dialectical discussion and reasoning without ascribing to any established school of thought of the past. With his masterful works, it tries to challenges and draws our consciousness of the real force of intellectualism that was derived from scientific reflection and critical philosophical inquiry. It's strength was derived from the empirical and historic method and framework in his effort to formulate and comprehend classical Islam and its intellectual tradition in term of its contextual and modern understanding and process.
\end{abstract}

Keywords: Argumentative, Intellectualism, Modernization, Nurcholish Madjid.

\begin{abstract}
Abstrak: Tulisan-tulisan Nurcholish Madjid yang luar biasa baiknya itu, seolah ingin mengajak khalayaknya untuk berargumen dan berdialog dengannya dengan sebebas-bebasnya, tanpa peduli pada sanggahan atau tudingan anarkis. Tulisan-tulisan yang kental dengan himbauan falsafah yang mengilhamkan itu bertujuan memupuk kekuatan dan kemauan dialog tanpa terikat dengan pandangan mazhab manapun. Dengan karyakarya intelektualnya, Ia coba menghimbau kesadaran intelektual masyarakat terhadap dasar dan kekuatan intelektualisme yang dikembangkan dari pengamatan saintifik dan pikiran-pikiran falsafah yang kritis. Ia menarik kekuatan dari nilai-nilai empirik dan historis dan merumuskan pemikiran dan pemahaman Islam klasik dalam kerangka modern dan kontekstual.
\end{abstract}

Kata kunci: Argumentatif, Intelektualisme, Modernisasi, Nurcholish Madjid

\section{PENDAHULUAN}

Nurcholish Madjid dilahirkan pada 17 Maret 1939 (26 Muharram 1358 Hijrah) di Mojoanyer, Jombang, Jawa Timur. Ia merupakan pelopor penting gerakan pembaharuan Islam di Indonesia. Berasal dari keluarga pesantren dalam tradisi Nahdliyin, ayahnya, K.H. Abdul Madjid, termasuk salah seorang pelopor Masyumi dan juga kiyai jebolan Pesantren Tebuireng, Jombang, yang diasaskan oleh Hadratus Syaikh Hashim Asy'ari, pendiri Nahdlatul Ulama (NU). Ibunya Hajjah Fathonah Mardiyyah, adik dari Rais Akbar NU dari ayah seorang aktivis Syarikat Dagang Islam (SDI). Nurcholish merupakan anak sulung dari 4 bersaudara. Kebiasaan pagi Ia memasuki Sekolah Rakyat (Madrasah Ibtidaiyah) di Mojoanyar, Jombang, dan Bareng dan petangnya mengaji di Madrasah al-Wathaniyyah, pimpinan ayahnya sendiri. Nurcholish sejak kecilnya telah menghadam koleksi lengkap kitab-kitab yang dimiliki ayahnya. Selanjutnya ia ke Pesantren Darul 'Ulum, Rejoso, Jombang (tingkat menengah SMP dan SMA) di kota yang sama, menempuh pengajian menengahnya.

Ia beafiliasi dengan Masyumi dan pindah ke pesantren modernis, yaitu Kulliyyat alMu'allim al-Islamiyyah (KMI) pondok pesantren Darussalam di Gontor, Ponorogo, Jawa Timur. Ia menamatkan studinya pada 1960. Pengalaman pendidikan selama enam tahun, telah membentuk pandangan hidup dan akar Islamnya semakin kritis dengan keluasan pandangan dan pemahaman mazhab yang mendalam, sebagaimana dipaparkan oleh Hidayat (Madjid, 1995): Iklim pendidikan yang diterimanya mengajarkan untuk berpikir kritis, tidak memihak

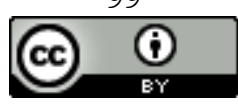

This work is licensed under a Creative Commons Attribution 4.0 International License 
VOLUME 14 NOMOR 1 TAHUN 2021

P-ISSN : 1979-9357

E-ISSN : 2620-5858

pada salah satu madzhab secara fanatik dan, lebih dari itu, kemampuan berbahasa Arab serta Inggris sangat ditekankan agar para santri mampu melihat dan menyadari bahwa dunia ini begitu luas.

Reformasi pemikiran Islam pesantren (Rachman, 2019) ini pernah disuarakan Cak Nur, dan Jika pesantren tidak mampu memberi respons yang tepat, maka pesantren akan kehilangan relevansinya, dan akar-akarnya dalam masyarakat akan tercerabut dengan sendirinya, dengan segala kerugian yang bakal ditanggung (Madjid, Bilik-bilik Pesantren: sebuah potret perjalanan, 1997). Pembentukan pemikiran dalam tradisi intelektual pesantren inilah yang mendorongnya menggerakkan cita-cita perjuangan dan pembaharuan (Sofyan $\&$ Madjid, 2003). Pengaruh dan kekuatan pondok Gontor ini dalam mencetak angkatan kader dan pemuka Islam yang masyhur pernah dikupas oleh Hamka bahwa sudah menjadi semacam tradisi pembentukan kader yang kelak akan menyebarkan Islam ke pelosok-pelosok yang jauh (Hamka, 2012).

Pada perkembangan selanjutnya, Cak Nur juga berperan sebagai penggerak dan eksponen Himpunan Mahasiswa Islam (HMI) (Effendi \& Natsir, 1981), pada organisasi kemahasiswa ini, Ia melemparkan gagasan-gagasan sederhana dan menggegarkan di mana tulisan-tulisannya secara berkala diterbitkan di tabloid Mimbar Demokrasi dan mulai melancarkan gerakan pembaharuan pemikiran dan merumuskan ide-ide dan pemahamanpemahaman Islam yang rasional dan gagasan-gagasannya yang moderat. Menurutnya bahwa modernisasi adalah rasionalisasi, bukan penerapan sekularisme dan bukan pula pengagungan nilai-nilai kebudayaan Barat (Madjid, Demi Islam - demi Indonesia, 1999). Karena pemikirannya inilah sehingga Ia dijuluki sebagai "Natsir Muda” (Rachman, 2019).

Dari pengalaman inilah, kemudian Ia berusaha mempersiapkan dan menggariskan khittah dasar perjuangan menghadapi tantangan dan pengaruh-pengaruh yang menantang ideologi Islam di masa Orde Baru dan pertikaian-pertikaian ideologis yang memuncak dengan kelompok-kelompok nasionalis dan komunis (Madjid, Demi Islam - demi Indonesia, 1999). Meskipun mendapatkan penolakan dan kritik dari banyak pihak di HMI (Effendi \& Natsir, 1981), pada akhirnya, Ia terpilih menjadi Presiden PEMIAT yang kemudian telah membuka kesempatan untuknya ke luar negeri dan berkumpul dengan rekan-rekannya yang lain (Ibrahim, 2008.).

Tahun 1986, Nurcholish membentuk Yayasan Wakaf Paramadina, sebuah lembaga tempat Ia dan teman-teman secara bebas dan leluasa menyusun aktivitasnya dan mengembangkan wawasan dan fikiran. Gerakan intelektual ini kemudiannya dikenal sebagai Gerakan Pembaruan Keagamaan, di mana menurut Moeslim Abdurrahman, "Gerakan Cak Nur adalah gerakan ide, diperlukan mekanisme yang bisa lebih efektif untuk menggerakkan kaki-kaki ide tersebut (Rachman, Ensiklopedi Nurcholish Madjid, Pemikiran Islam di Kanvas Peradaban, 2006). Dari kelompok pembaruan ini ia berhasrat untuk mewujudkan masyarakat yang berperadaban. Dan sejak pertemuannya dengan Seyyed Hossein Nasr di Paramadina pada 1992, mazhab pemikiran Islam Paramadina telah diwarnai oleh filsafat perennial, yang dipelopori Nasr, bersama Fritjhof Schuon (Muhammad Isa Nuruddin) dan Martin Ling (Abu Bakar Sirajuddin).

Cak Nur adalah bintang paling cemerlang di langit intelektual Indonesia (Fatah, 2005). Artikel ini berusaha untuk melacak pemikiran Prof. Dr. Nurcholish Madjid dan melihat sisisisi argumentatifnya dalam penghujahan dan ide-ide dan hujahnya yang kritis. Ia mengungkapkan aspirasi dan pandangan-pandangannya yang inklusif-pluralis dan kritisempiris terkait dengan permasalahan-permasalahan teologi, budaya, peradaban, hukum, 


\section{VOLUME 14 NOMOR 1 TAHUN 2021 \\ P-ISSN : 1979-9357 \\ E-ISSN : 2620-5858}

falsafah, fiqh, kalam, dan syariat. Prasaran-prasaran dan argumen-argumennya yang menarik dan sederhana yang diajukan terkait dengan ide-ide perubahan, prinsip musyawarah, demokrasi, modernisasi, sekularisasi, desakralisasi, dan pluralisme ini memperlihatkan keluasan jangkauan fiqh dan pandangan sosio-religius yang dirumuskan dengan pemahaman kontekstual-historis yang kritis. Ia cuba melihat kekuatan pengaruh dan keluasan pandangan dan hujahnya dalam membawa gagasan-gagasan pembaharuan dan menggembling ide-ide perubahan dan kemodernan dalam konteks keislaman di Indonesia.

\section{METODE PENELITIAN}

Penelitian ini merupakan penelitian literatur (studi pustaka) dengan pendekatan kualitatif. Mengkaji mengenai narasi-narasi yang ditemukan pada teks-teks bacaan dari sumber primer dan sumber sekunder penelitian.

\section{HASIL PENELITIAN}

\section{Hasil karya}

Kekuatannya sebagai pemikir terefleksi dari karya-karyanya yang berpengaruh yang menghimpunkan tulisan-tulisan dan rencana-rencananya yang kritis yang menyorot tematema dasar seputar aspirasi pembaharuan dan gagasan-gagasan Islam yang progresif. Idealisme dan paham-paham progresif ini dilakarkan dalam buku-bukunya seperti Islam Doktrin dan Peradaban (1992); Islam Agama peradaban, membangun makna dan relevansi doktrin Islam dalam sejarah (1997); Pintu-pintu menuju Tuhan (1995); Islam agama kemanusiaan (1995); Kaki Langit Peradaban Islam (1997); Masyarakat Religius (1997); Tradisi Islam (1997); Sekularisasi dan Modernisasi; Khazanah Intelektual Islam (ed.) (1988) dan lain-lainnya.

Dari karya-karyanya ini Ia berusaha mengungkapkan persoalan-persoalan dasar tentang teologi, budaya, agama, masyarakat madani dan sekularisasi dari segi pandangan dunia yang dinamik dan rasional. Ia menzahirkan kekuatan intelektual yang mengagumkan dari analisis-analisis dan bentuk-bentuk pemikiran yang dirumuskan tentang pandanganpandangan religius dan paham-paham budaya dan peradaban. Dan hal ini merupakan tematema yang meluas dan berpengaruh yang membentuk kerangka dasar dari teologi yang diperjuangkan dan gagasan-gagasan yang signifikan yang digerakkannya seputar isu-isu konstitusional, konsep masyarakat madani, prinsip musyawarah, paham-paham religius, dan ajaran-ajaran progresif tentang semangat rasionalisme, pluralisme, modernisme dan sebagainya.

\section{Pancasila}

Cak Nur mengumandangkan Islam secara Indonesia dan mendendangkan Indonesia secara Islam, sampai batas antara keduanya sedemikian transparan. Ia menjelaskan kemodernan dan Islam sampai tak bisa dibedakan lagi (Nadjib, 2019). Dalam percaturan politik Indonesia, Nurcholish mempunyai peranan yang instrumental dalam mendesak pengunduran Presiden Soeharto. Ia menyanggah kebobrokan rezim Soeharto dan kesewenangannya menindas Pancasila dan menolak proses demokratik. Pemerintahan Soeharto menggunakan Pancasila untuk mengekang kebebasan agama dan memaksa penerimaannya secara semberono.

Dalam percobaan untuk menundukkannya kepada hukum dan menangkis ketegangan yang ditimbulkan, Nurcholish berusaha merekonstruksi nilai-nilai dan menguatkan landas 
VOLUME 14 NOMOR 1 TAHUN 2021

P-ISSN : 1979-9357

E-ISSN : 2620-5858

ideologis yang dirangkul Pancasila. Menurutnya Pancasila adalah platform umum (common platform) antara berbagai macam kelompok masyarakat dan agama. Ia merupakan titik temu di antara mereka. Pancasila adalah kontrak sosial atau 'aqd yang mengikat seluruh bangsa Indonesia. Dari segi sejarah Pancasila telah menunjukkan keberkesanannya sebagai tiang seri kepada bangsa Indonesia. Meskipun begitu, pengoperasian yang maksimum dari nilai-nilai Pancasila masih memerlukan perjuangan yang panjang. Cabarannya adalah bagaimana menjadikan Pancasila berfungsi sepenuhnya sebagai sumber dalam membina masa depan. Nurcholish mengajukan formula yang menarik, yaitu dengan menjadikan Pancasila ideologi yang terbuka.

Menurutnya meskipun Pancasila itu sebagai etika bangsa baru mantap pada tingkat formal-konstitusional, tetapi peragiannya yang bisa diperoleh dari beberapa sumber termasuk sumber Islam - yang akan memperkaya proses pengisian etika Politik Pancasila tersebut (Rachman, Karya Lengkap Nurcholish Madjid, 2019). Dalam konteks ini, Pancasila adalah kalimatun sawa' (titik temu - common ground) yang mengajak semua orang untuk tunduk kepada kepercayaan Tuhan. Poinnya adalah untuk menghargai keanekaragaman dan kemajemukan yang ada dalam masyarakat. Dengan penghargaan ini kehidupan yang aman dan harmonis dapat direalisasikan (Madjid, Islam agama kemanusiaan: membangun tradisi dan visi baru Islam Indonesia, 1995).

Dalam merumuskan hal ini Nurcholish menjelaskan ada sumber-sumber pandangan etis yang meluas dan dominan, yang secara sangat potensial bisa menjadi pandangan etis bangsa secara keseluruhan, dan yang bisa dijadikan bahan pengisian wadah etika Pancasila. Yaitu pertama, etika kebangsaan Indonesia yang perwujudan paling baiknya dan penampakan paling dinamisnya ialah bangsa Indonesia. Kedua, etika kemodernan yang merupakan akibat langsung keberadaan kita di abad modern. Ketiga, etika Islam, yang sebagai anutan rakyat merupakan agama paling luas menyebar di seluruh tanah air, dan yang peranannya diakui para ahli sebagai perata jalan untuk tumbuhnya paham-paham maju dan modern di kalangan rakyat kita, khususnya dalam bentuk paham persamaan manusia (egalitarianisme) dan pengakuan serta penghargaan kepada adanya hak-hak pribadi, selain paham hidup menurut aturan atau hukum (pengaruh langsung sistem syariah), dan weltanschauung yang lebih bebas dari takhayul (Madjid, Tradisi Islam: peran dan fungsinya dalam pembangunan di Indonesia, 1997).

\section{Warisan Intelek}

Legalitas dan warisan pemikirannya yang meluas dalam tradisi intelektual Islam dan pengaruhnya yang penting sebagai pembela pluralisme dan kebebasan berfikir dan tokoh Islam kultural, dan lokomotif pembaharuan pemikiran Islam, dihimbau oleh ahli sejarah Taufik Abdullah yang menyebutnya sebagai one of the most creative Islamic intellectuals in contemporary Indonesia (Woodward, 1998). Sikapnya yang pragmatik dan pembelaannya terhadap ajaran dan nilai-nilai kesederhanaan, prinsip musyawarah dan paham kebebasan dan penganjurannya terhadap Islam yang bergaris sederhana, dengan berkesan dirumuskan oleh Hasnan Bachtiar "ia berdiri di tengah secara moderat, otonom dan tentu saja merdeka. Tidak hanya itu, ekspresi pemikirannya begitu jelas, bermuatan penghayatan yang mendalam, disampaikan dengan diksi yang sederhana dan mampu dimengerti oleh khalayak ramai (Bachtiar, 2011). 
VOLUME 14 NOMOR 1 TAHUN 2021

P-ISSN : 1979-9357

E-ISSN : 2620-5858

Eep Saefullah pernah mengungkapkan tentang kesahajaan sosok Cak Nur sebagai penasehat dalam memahami keadaan, secara saksama dan cermat berbasiskan kesahajaan fakta, kejujuran, dan obyektivitas. Maka bukan hanya ceramah agamanya yang terasa sejuk, analisis dan kesaksian Cak Nur atas keadaan hampir selalu tepat dan mencerahkan (Fatah, 2005). Kekuatan pengaruhnya yang meluas dalam tradisi akliah dan pemikiran pembaharuan ini, dikatakan oleh Dr Daud Rasyid dalam bukunya yang membayangkan "sihir Nurcholish" lebih canggih dan lebih memukau daripada sihir Harun Nasution (Rasyid, 1993).

\section{Pembela HAM (Hak asasi manusia)}

Pada 1993, Ia menjadi anggota KOMNAS HAM (Komite nasional hak asasi manusia). Ide HAM-nya yang prinsipal, digarap dan dimuatkan dalam salah satu tulisannya, "Memahami kembali makna pidato perpisahan Nabi (saw)" di mana ia menekankan pentingnya agama yang memihak kepada kemanusiaan, yang mendasari dan memaknai nilai-nilai manusiawi, di mana "manusia tidak boleh saling menindas, tidak boleh ada exploitation de' l'homme par l'homme. Pendirian dan falsafah HAM-nya sejalan dengan pemikiran-pemikiran teolog dan perumusanperumusan klasik Islam (Monib \& Bahrawi, 2011).

\section{Desakralisasi dan Sekularisasi}

Tahun 1970 merupakan tahun yang benar-benar penting dalam kehidupannya. Karena pada awal tahun itulah, Ia melontarkan pemikiran tentang pembaruan pemikiran Islam yang kemudian menimbulkan kontroversi dan kehebohan (Madjid, Demi Islam - demi Indonesia, 1999). Ide modernisasi yang dilemparkan Nurcholish ini pernah mendapat catatan dari Ahmad Wahib - yang terlingkung dalam elitis Limited Group yang dibentuknya di Yogyakarta: Pertama harus diketahui bahwa proses desakralisasi itu tertuju pada masalah-masalah yang sesungguhnya tidak sakral, tapi selama ini dianggap sakral, yang karenanya perlu dikembalikan pada status yang tidak sakral dengan proses desakralisasi. Kedua kita harus bertanya, masalah-masalah mana yang tergolong masalah sakral dan masalah non-sakral. Adakah dalam Islam perbuatan-perbuatan yang non-sakral? Kesulitannya terletak dalam dua pandangan memakai sakral yaitu sakral dalam arti suci dan sakral dalam arti upacara suci. Di sinilah terletak "kurang tepatnya istilah desakralisasi (Effendi \& Natsir, 1981).

\section{Ilmu Sosial}

Nurcholish sering memperhatikan permasalahan-permasalahan yang diselidikinya dari segi ilmu sosial, dengan analisis-analisis saintifik yang bercorak empiris dan historis yang kritis, di mana "Cak Nur-lah yang pertama kali memelopori gairah baru intelektualisme di perguruan tinggi agama dengan menyuntikkan analisa ilmu-ilmu sosial (Muhtadi, 2008). Kekuatan dan kefahaman yang dirumuskan dari pemakaiannya terhadap ilmu-ilmu sosial ini dicatatkan oleh Burhanuddin Muhtadi "Satu hal yang perlu saya catat khususn Cak Nur adalah pionir intelektual Muslim yang memperkenalkan ilmu-ilmu sosial dalam membedah persoalan keagamaan di Indonesia.

Menurutnya, peran dalam menjelaskan fenomena keislaman dalam kerangka ilmu sosial dapat ditinjau dari tiga segi, pertama tesisnya bahwa modernisasi adalah rasionalisasi bukan pembaratan atau westernisasi. Kedua, urgensi pembaruan keislaman yang diusungnya meniscayakan peran ilmu-ilmu sosial. Lantaran itu, argumen-argumennya seputar persoalan keislaman di Indonesia sering tidak sekadar normatif, tetapi juga sosiologis-antropologis.

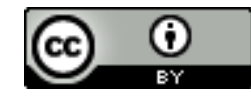

This work is licensed under a Creative Commons Attribution 4.0 International License 
VOLUME 14 NOMOR 1 TAHUN 2021

P-ISSN : 1979-9357

E-ISSN : 2620-5858

Ketiga, tatkala ia meramalkan timbulnya intellectual boom di kalangan Muslim, ia merumuskan analisa Clifford Geertz seputar trikotomi santri, priyayi dan abangan, dan mengaitkannya dengan perkembangan sosial umat Islam Indonesia yang kemudian melahirkan proses santrinisasi (Muhtadi, 2008).

Maka, pada intinya, Ia berhasil memperlihatkan bahwa Islam tidak hanya mempunyai dimensi teologis, malah politis, historis dan antopologis. Ia secara piawai mendialogkan Islam dengan permasalahan-permasalahan yang bersifat kontekstual, historis dan empiris. Pada pengamatan Burhanuddin, hal ini diperlihatkan tatkala Nurcholish melemparkan gagasan seputar desakralisasi partai Islam. Hujahnya selain diperkuat dengan teologis yang kuat, ia juga membela ideanya dengan argumen-argumen sosial-historis yang tangguh.

Ide sekularisasinya, telah menimbulkan polemik dan mendapat resistensi yang kuat, dan keras disanggah oleh Prof. H. M Rasyidi. Namun ini telah dipatahkan oleh Cak Nur, dimana ia tidak lah mentah-mentah mengadopsi teori sekularisme ala Harvey Cox, sebaliknya merumusnya sesuai dengan konstruk ideologi, sosial dan politik Indonesia. Hal ini juga sebagai ditunjukkan Bahtiar Effendy dimana Cak Nur sekadar memakai ilmu-ilmu sosial sebagai alat analisis untuk menjelaskan fenomena sosio keagamaan dan gejala-gejalanya di Indonesia dan ini sulit dibantah.

Pembaharuan yang dipelopori dan isu-isu reformasi keagamaan dan desakralisasi yang digaungkan telah memberikan sumbangsihnya dalam mempertahankan nilai-nilai kemodernan. Penelitiannya tentang isu-isu keislaman mutakhir, terus mendengungkan pemikiran dan gagasan keislaman modern yang bersifat sosial-historis dan empiris.

\section{KESIMPULAN}

Pemikiran-pemikiran inklusif-pluralis dan sosio-religius yang digagaskan dari fikiranfikiran dan penyelidikan-penyelidikannya yang ekstensif dan berpengaruh itu telah mengilhamkan kesedaran dan membawa pembaharuan di dunia Islam. Nilai-nilai kebebasan, dan toleransi yang digemblengnya kini menginspirasikan beberapa usaha yang digerakkan oleh ICMI, Yayasan Paramadina, Universiti Paramadina, Yayasan Abad Demokrasi dan NurcholishMadjid Society dalam mengembangkan idealisme dan paham-paham moden yang berpengaruh yang pernah dirintisnya. Falsafah dan gagasan-gagasan yang dilontarkan dari kemuncak pemikirannya itu telah dimuatkan dalam Ensiklopedi Nurcholish Madjid (selenggaraan Budhy Munawar-Rachman) yang memuatkan intisari pemikirannya yang menyeluruh tentang nilai-nilai perubahan dan pembangunan.

Ia mencerakinkan ide-ide dan pemikirannya yang ekstensif dari seluruh karyakaryanya yang besar. Karya lengkap ini cuba memperkenalkan ideologi pemikiran dan gagasan-gagasan yang pernah digaungkan Nurcholish dalam menggembling prinsip inklusivisme dan pluralisme dan paham toleransi antara umat "yang mendapat sambutan gegap gempita di Indonesia". Ini diilhamkan dari kemuncak pemikirannya tentang metodemetode kalam dan falsafah dan keyakinan dan semangat tawhid yang telah mencorakkan idealisme dan pemikiran-pemikiran sosial dan keagamaan yang berpengaruh di Indonesia.

\section{DAFTAR PUSTAKA}




\section{VOLUME 14 NOMOR 1 TAHUN 2021}

P-ISSN : 1979-9357

E-ISSN : 2620-5858

Bachtiar, H. (2011). Memikirkan-ulang khazanah HAM Cak Nur. Jakarta: Gramedia Pustaka Utama.

Effendi, D., \& Natsir, I. (1981). Pergolakan Pemikiran Islam, Catatan Harian Ahmad Wahib. Jakarta: LP3ES (Lembaga Penelitian, Pendidikan dan Penerangan Ekonomi dan Sosial).

Fatah, E. S. (2005, Agustus 30). Cak Nur, Pemelihara Ingatan. pp. 1-5.

Hamka. (2012). Prinsip dan Kebijaksanaan Dakwah Islam. Shah Alam: Pustaka Dini.

Ibrahim, A. (2008., Juli 14). Natsir, Politikus Intelektual.

Madjid, N. (1995). Islam agama kemanusiaan: membangun tradisi dan visi baru Islam Indonesia. Jakarta: Yayasan Wakaf Paramadina.

Madjid, N. (1995). Islam agama peradaban: membangun makna dan relevansi doktrin Islam dalam sejarah. Jakarta: Yayasan Wakaf Paramadina.

Madjid, N. (1997). Bilik-bilik Pesantren: sebuah potret perjalanan. Jakarta: Paramadina.

Madjid, N. (1997). Tradisi Islam: peran dan fungsiny a dalam pembangunan di Indonesia. Jakarta: Paramadina.

Madjid, N. (1999). Demi Islam - demi Indonesia. Jakarta: Paramadina.

Monib, M., \& Bahrawi, I. (2011). Islam dan Hak Asasi Manusia dalam Pandangan Nurcholish Madjid. Jakarta: Gramedia Pustaka Utama.

Muhtadi, B. (2008). "Ke Cak Nur aku "mengaji” Cak Nur di mata anak-anak muda. (A. Armando, Ed.) Jakarta: Paramadina.

Nadjib, E. A. (2019). Nurcholish Madjid - Profil dan Pemikirannya. Jakarta: Tempo Publishing.

Rachman, B. M. (2006). Ensiklopedi Nurcholish Madjid, Pemikiran Islam di Kanvas Peradaban. Jakarta: Mizan \& Yayasan Wakaf Paramadina.

Rachman, B. M. (2019). Karya Lengkap Nurcholish Madjid (xxxiv ed.). Jakarta Selatan: Nurcholish Madjid Society (NCMS).

Rasyid, D. (1993). Pembaruan Islam dan Orientalisme dalam Sorotan. Jakarta.

Sofyan, A. A., \& Madjid, M. R. (2003). Gagasan Cak Nur tentang negara e Islam. Yogyakarta: Titian Ilahi Press.

Woodward, M. R. (1998). Islamisasi Kapitalisme: Tentang Pembentukan Bank Islam PertamaJalan Baru Islam, Memetakan Paradigma Mutakhir Islam Indonesia. (I. A. Fauzi, Ed.) Bandung: Mizan. 